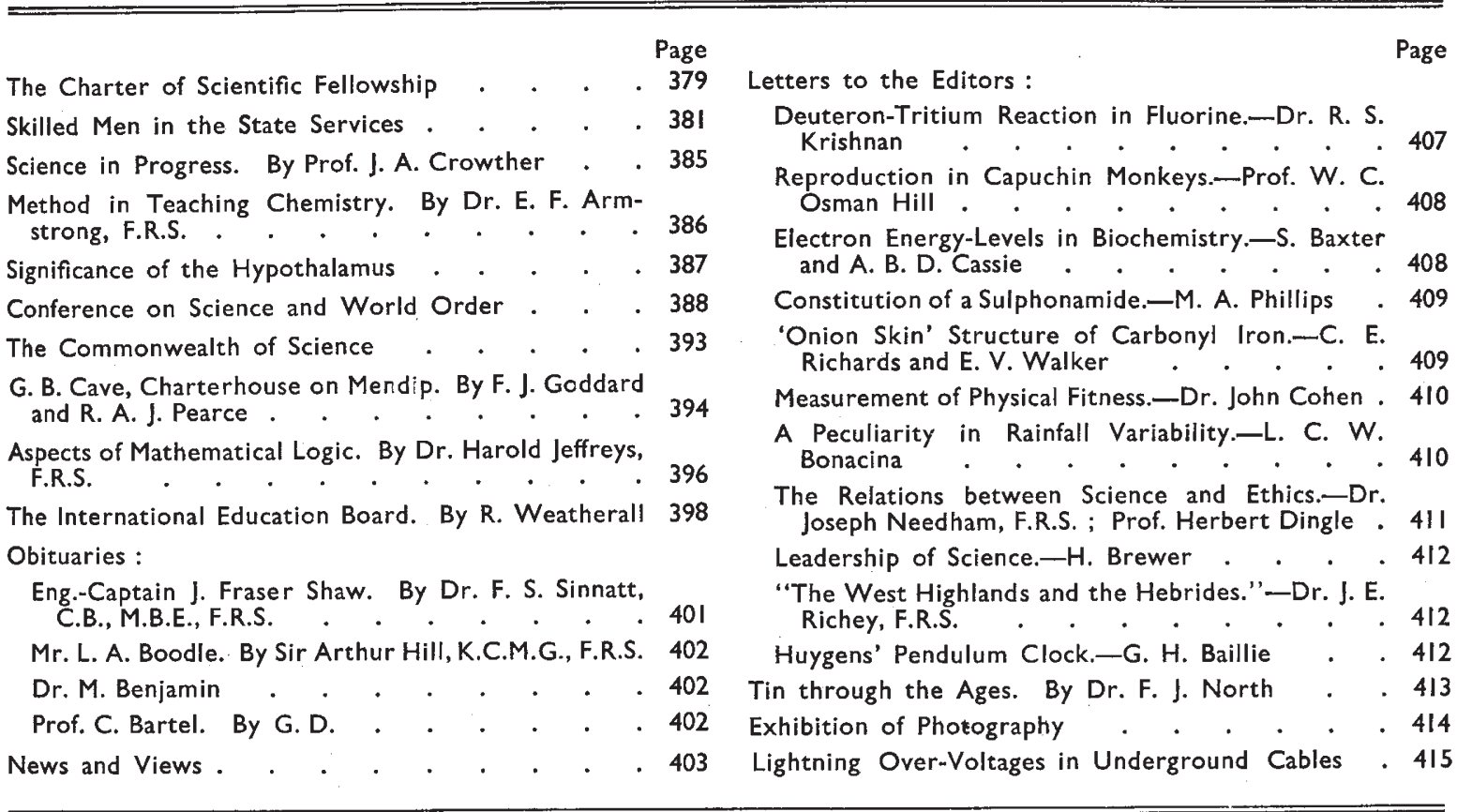

\title{
THE CHARTER OF SCIENTIFIC FELLOWSHIP
}

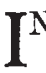
the conflict of ideas, the clash of two diametrically opposed ways of living, which are involved in the present War, the British Association's recent Conference on Science and World Order may well prove to have as profound a significance as President Roosevelt's clear enunciation of the four freedoms which are at stake, and as the declaration which arose out of his Atlantic meeting with Mr. Churchill. In place of the thoughtless blaming of science for the misuse of the knowledge and power with which scientific discoveries and their application have endowed mankind, we have the recognition that from henceforth science and statecraft, in Mr. Eden's words (see p. 403), must march together.

Nor is this all. The very holding of such a meeting in war-time, a meeting as truly international as the meeting of the Inter-Allied Council held also in London in the same week, attests the existence of the goodwill and faith in international co-operation required to lay the foundations of a better world. The merest glance at the programme of the Conference will have revealed how profound is the contribution of science to that task ; and how grave is the responsibility of statecraft to see that the fruits of planning by men of science are not misused, and to secure the free enjoyment by all of the greater health and leisure which science has made possible.
What is equally significant is that this partnership of science and statesmanship in the building of a new world order is only possible in the nations that still remain free. Without full freedom science cannot long persist, for the fountain heads of new knowledge and creative thought dry up and the quest for truth degenerates into the practice of a technique or cult. This we have already seen happening in Germany, though as many countries know to their cost, science is not yet dead in that country. None the less, the persistent interference with freedom of scientific investigation, of the expression of scientific thought, and with the international interchange of thought had already some time before the War led to a marked deterioration in the quality of scientific work in Germany, especially in fields of new and fundamental research. The British Association Conference in itself is a welcome reminder of the immense and incalculable assets, which are ours in the struggle against Nazism, through the international exchange of scientific thought still possible among the free peoples and the exiled men of science in their midst.

These are truisms obvious to any scientific worker, but it is well that they should be so clearly stated for a wider public, as has been done in the Declaration of Scientific Principles adopted at the final session of the Conference (see p. 393). The 
Declaration indeed contains nothing new. It is an educational instrument of the first order, and if it is studied aright by scientific workers and by statesmen and administrators, there should be an end to the charge that in Great Britain, ministers of State or the Civil Servants under them are insufficiently equipped in scientific knowledge or grasp of scientific method and technique.

This Declaration of Scientific Principles is no mere statement of the conditions upon which such co-operation is possible. It demonstrates first and foremost the extent to which the future of science is bound up with that of democracy and the overthrow of Nazism. This struggle is part of the agelong struggle of scientific workers to preserve freèdom of thought, of investigation and of expression in the face of unreasoning prejudice, stagnation and repression. The Declaration is an open renunciation of neutrality and an acceptance of special responsibility in the struggle against a tyranny which threatens to overwhelm intellectual liberty everywhere.

The acceptance of such responsibilities is not, however, prompted by the mere instinct of selfpreservation, the conviction that to-day complete freedom of thought and interchange of knowledge and opinion are supreme necessities. It is equally prompted by a consciousness of the harmony of interests and aspirations between science and democracy itself. As the Declaration insists, full freedom of expression is of the essence of both science and democracy: where thought is enslaved both wither and decay.

More than this, since the direction of and resources available for scientific work are determined by the social and economic conditions in which the scientific worker finds himself, science is equally concerned with the economic freedom, the third freedom enunciated by President Roosevelt, and all that is implied in the adjustments of social and economic life, required for its realization. This is not merely a matter of the application of scientific knowledge or the mobilization of scientific resources for the acquisition of fresh knowledge in fields insufficiently explored. It is a question of outlook, of the adjustment of ways of living to facilitate the full and free adaptation of ideas to new conditions.

If, therefore, the Declaration of Scientific Principles is an affirmation of those principles upon which it has long been recognized that the fellowship of science is based, and of opposition to any policy of power which deprives men or nations of their free practice, it is equally a challenge to intense mental effort and clear vision. The vision of the possibilities inherent in the contribution of science to the solution of post-war problems and to the building of a nobler world order which the deliberations of the Conference have given, needs to be supplemented by exactly such a statement of principles and challenge to thought and endeavour.

It is well, therefore, that all should understand the basic implication that science must be the partner, not the handmaid, of the statesman or administrator. The State must impose no limits on liberty to learn, opportunity to teach or power to understand if society is to reap the full advantages of scientific thought and knowledge. Science can co-operate while retaining its independence. To sacrifice its independence may destroy cooperation by destroying science.

That truth can scarcely be emphasized too strongly to-day, and there was no more hopeful sign at the Conference than its ready acceptance by Government spokesmen as by the spokesmen of science. Equally vital is the stress laid in the sixth and seventh points of the Declaration on the world fellowship of science. Science truly has the world for its province, and the discovery of truth as its highest aim. The pursuit of scientific inquiry demands unrestricted international exchange of knowledge as well as complete intellectual freedom, and can only flourish through the unfettered development of civilized life. The Conference itself bears witness to the extent to which such international fellowship is still possible in Great Britain and to the hope which may justly be entertained of re-establishing it in Europe when the Nazi power has been destroyed. It may well be hoped, however, that the Conference with this pointed Declaration will stir us to use far more effectively than hitherto the immense moral and intellectual resources in international co-operation which we possess, not alone through our allies but also through the presence of émigré men of science from Germany and the occupied countries of Europe.

Any partnership must be based on mutual understanding and respect. No scientific worker, therefore, can fail to mark and honour the pledge given in the fifth point of the Declaration. Men of science are among the trustees of each generation's inheritance of natural knowledge. It is, as they attest, their determination to foster and increase that heritage by the fidelity of their guardianship and service to high ideals, shown to-day in their devotion in the defence of that heritage in the present struggle, no less than in the planning and thought which must go to safeguarding it in a new order yet to be. To scientific workers no less than to the administrator or statesman, the Declaration is a summons to thought and action. To both it may well bring the reflection : noblesse oblige. 